\title{
Methodology for GD\&T Verification in an Innovative Benchmark Part for Contactless Scanning Systems
}

\author{
Vimal Kumar Pathak \\ Assistant Professor \\ Manipal University Jaipur \\ Department of Mechanical Engineering \\ Jaipur, Rajasthan \\ India
}

\begin{abstract}
Ashish Kumar Srivastava
Assistant Professo

Manipal University Jaipur

Department of Mechanical Engineering Jaipur, Rajasthan

India
\end{abstract}

Sumit Gupta

Assistant Professor Amity School of Engg. \& Tech. Department of Mechanical Engineering Amity University Uttar Pradesh

This paper presents an innovative method to investigate the accuracy and capability of contactless laser scanning systems in terms of geometrical dimensioning and tolerancing (GD\&T) control. The current work proposes a standard benchmark part with typical features conforming to different families of GD\&T. The benchmark part designed consists of various canonical features widely used in an engineering and industrial applications. Further, the adopted approach includes the methodology for comparison of geometry using a common alignment method for contactless scanning system and a CMM. In additon, proposal of different scanning orientation methods for contactless system is also realized. Surface reconstruction of the benchmark model is achieved using different reverse engineering software, and results are analyzed to study the correlation between different geometries of contact and contactless system. Considering the contact based measurement as a reference, different models developed were analyzed and compared in terms of geometrical and dimensional tolerance. The proposal of standard benchmark part and methodology for GD\&T verification will provide a simple and effective way of performance evaluation for various contactless laser-scanning systems in terms of deviations.

Keywords: GD\&T verification, benchmark part, contactless laser scanning, CMM, surface reconstruction.

\section{INTRODUCTION}

Nowadays, with the advent of rapid growth in manufacturing technologies like rapid tooling and rapid prototyping, manufacturing of competitive products with high complexity and anomalies, has become possible in aerospace [1], biomedical [2], automobile [3] and mould industries [4]. In these areas, product inspection has become an inevitable task in the life cycle of products, which normally takes a lot of manufacturing lead-time [5-6]. The geometrical dimensioning and tolerancing (GD\&T) inspection is used to examine the conformity of manufactured parts with the defined part specification.

Often, GD\&T inspection is performed using contact based coordinate measuring machines (CMM) in industries [7-8]. The main advantages are high measuring accuracy, point-to-point data acquisition and well established calibration process. However, inspection planning using CMM is a complex and troublesome task, which requires skilled and experienced operator [9]. The CMM inspection is effective for certain types of parts but not suitable for soft materials, complex geometry especially free form shapes. Furthermore, performing rapid data acquisition of part surface is one of the primary concerns, which is even higher for large

Received: April 2020, Accepted: June 2020

Correspondence to: Dr Vimal Kumar Pathak

Department of Mechanical Engineering, Manipal

University Jaipur, Jaipur, 303007 Rajasthan, India

E-mail: vimalpthk@gmail.com

doi:10.5937/fme2004899K

(C) Faculty of Mechanical Engineering, Belgrade. All rights reserved and complex parts. In industries, non-contact scanning systems are used as a tool for physical model restoration and development of complete and worn-out components [10]. Nowadays, contactless digitizing systems have realized an adequate level of assurance in reverse engineering field $[11,12]$. Further, significant efforts have been made to improve the accuracy of non-contact scanning systems [13]. However, the use of non-contact scanning instruments for industrial applications is impeded by investment particularly involving cost of instrument, software, training and timely maintenance.

For effective characterization and development of non-contact scanning systems, some standardized parts and methodology are required for providing adequate metrological data and quality claims. To test the quality claims of products, very few methods and techniques are available with industries. In addition, the selection of best method is quite tricky as the best technique for one application might not work for other. The lack of appropriate inspection standard makes it difficult for selection of a suitable scanning system only based on information provided by the manufacturer. The metrological specification provided by the manufacturers are based on the different systems, methods and are provided in the non-standard format which are difficult to translate in the real life applications.

Therefore, to investigate the potential offered by the non-contact scanning systems a common benchmark part and standard procedures are required. Such methods and benchmark parts will help the users in determining the strengths and weaknesses of a measuring system and hence, helps in the adequate decision ma- 
king process. In the same context, few examples of standards and guidelines provided for metrological verification using CMM is provided in the ISO 10360 and ISO 15530 [14-16].

Focusing on the metrological aspect, this paper presents an innovative benchmark part and a methodology to evaluate the suitability and effectiveness of the non-contact scanning systems for GD\&T inspection of parts. Additionally, the proposed benchmark part will serve as a standard tool in examining whether workpieces meet a set of tolerance specifications as defined using GD\&T terminology. In the same context, a comparative study between non-contact scanning system and touch probe coordinate measuring machine (CMM) has been realized by considering CMM measurements as reference. The reason for taking CMM as reference is its repeatability and precision of measurement. The benchmark part is scanned, and virtual model is developed, which is compared with the model developed using CMM. The accuracy of two systems (contact vs non-contact) has been analysed by performing comparisons between the reconstructed benchmark surfaces. Different scanning orientations were considered, and the best strategy is suggested for accurate results. In addition, the influence of different reverse engineering (RE) software, used in the processing of raw point data to a reconstructed surface, has also been considered.

\section{METHODOLOGY ADOPTED}

In the present study, two different sensors are used. For contact-based measurement, INSPECS RUBY 564 CMM model having touch probe tip of $2 \mathrm{~mm}$ is fitted with an indexable swinging head. The touch trigger probes with $0.5 \mu \mathrm{m}$ resolution and volumetric length measuring accuracy MPEE of the machine according to ISO- $10360-2$ is $2.5+\mathrm{L} / 350 \mu \mathrm{m}$. The MPEE is the acronym for maximum permissible error for length measurement and $\mathrm{L}$ is the effective length. For non-contact measurement, Steinbichler COMET L3D contact less scanning system was used. The version of COMET scanner utilized in the current study for data capturing has a resolution of $1 \mathrm{Mpx}$ and 1170 x 880 pixels available (Table 1). It is imperative to highlight that the accuracy of the CMM is approximately one order of magnitude higher than the non-contact scanning systems. Therefore, the CMM measurement is used as reference for the geometries of benchmark part. The outline of the adopted methodology is shown in Figure 1.

\subsection{Benchmark Part Design}

The accuracy of data acquisition systems can be evaluated when standard geometric entities are scanned in a single view. Commonly, the non-contact scanners involve multiple scans for complete capturing of complex parts. The number of views depend on the existence of occlusion due to the features of the component. Due to multiple scans, each point cloud needs to align and merged for developing a complete and accurate model of the object. These two processes (aligning and merging) results in some errors due to superposition of multiple point data. However, the contactless scanning system need to produce accurate models even after combining multiple point cloud data in one dataset for proving the effectiveness in quality control.

Table 1. COMET L3D scanner parameters [17]

\begin{tabular}{|c|l|c|l|}
\hline S. No. & Scanner Parameters & Value & Unit \\
\hline 1. & Camera Resolution & $1170 \times 880$ & $\mathrm{dpi}$ \\
\hline 2. & Measuring Field & 100 & $\mathrm{~mm}^{3}$ \\
\hline 3. & Measuring Volume & $92 \times 69 \times 60$ & $\mathrm{~mm}^{3}$ \\
\hline 4. & Point to point distance & 100 & $\mu \mathrm{m}$ \\
\hline 5. & Fastest measurement time & 2.5 & $\mathrm{sec}$ \\
\hline
\end{tabular}

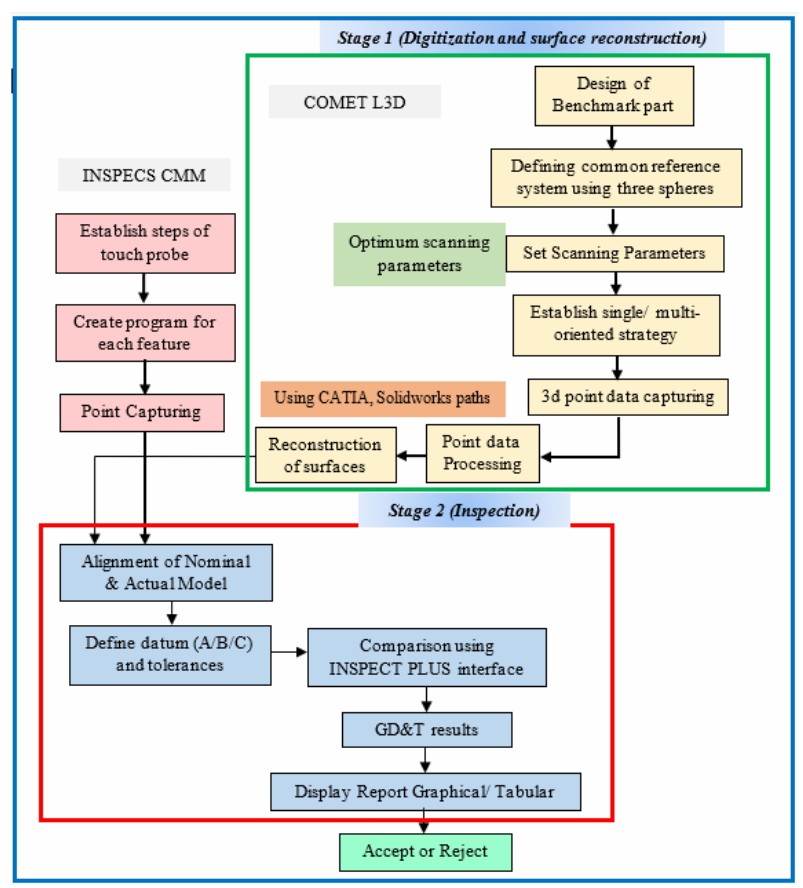

Figure 1. Proposed framework for GD\&T features verification in contactless scanning system

From quality control perspective, the existence of typical classic features is indispensable, since form errors and other geometrical tolerances are defined using them. The proposed benchmark parts were designed with reference to canonical GD\&T features used in regular engineering components. The test part designed includes different artefacts and primitives which are specifically selected to characterize variety of dimensions and geometries defined by GD\&T control. The overall dimensions of the benchmark part are $120 \times 120$ x $33 \mathrm{~mm} 3$ (see Figure 2). The size of benchmark part was determined to make it portable and fit into the working area of small contact based and contactless scanning systems. Additionally, the proposed standard artefacts have enough optical and geometrical features for providing error introduced by laser scanner with reference to contact based systems. The following classic geometries appear in the proposed benchmark parts: - An outer cylinder (OC), of $5 \mathrm{~mm}$ high. The cylinder has a diameter of $25 \mathrm{~mm}$.

- Three similar blocks with flat surfaces (FS), that are parallel and perpendicular to the part base. The dimensions of each block is $20 \times 10 \times 10 \mathrm{~mm}$.

- $\quad$ Five inner cylinders (IC). The biggest (IC1) has a diameter of $20 \mathrm{~mm}$, the second (IC2) has a diameter of 
$15 \mathrm{~mm}$. The third (IC3) and fourth (IC4) has dia. of 12 and $10 \mathrm{~mm}$ respectively. The smallest (IC5) cylinder is in between the four ICs having dia. of $5 \mathrm{~mm}$.

- A stair step (SS) having five steps of equal size. The height of each step is $4 \mathrm{~mm}$.

- Three triangular pyramids (TP). The side faces of TP1 are tilted to the apex of the pyramid with angle of $63.4^{\circ}$. For TP2 side faces are inclined at $61.7^{\circ}$. In third pyramid TP3, side faces are tilted with angle $60^{\circ}$.

- Two half-cylinders (HC). The outer half cylinder (OHC) and inner half cylinder (IHC) both has a radius of $4 \mathrm{~mm}$.

- A rectangular notch (RC), having depth of 6.75 $\mathrm{mm}$ from part top surface. The width of the notch is 4 $\mathrm{mm}$.

- Three angular Notches (AN). The first (AN1) has angle of $90^{\circ}$. The second (AN2) and third (AN3) notch has angle of $70^{\circ}$ and $72.6^{\circ}$.

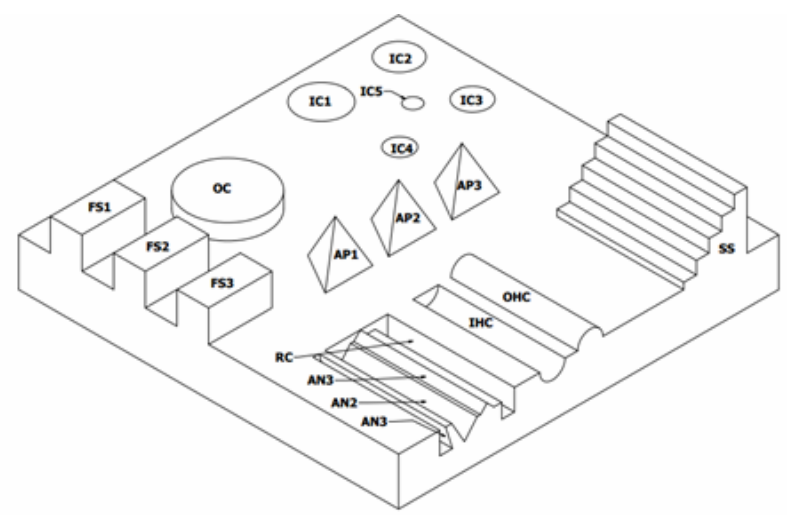

Figure 2. Proposed benchmark part with nomenclature

In this work, the manufacturing of the proposed benchmark part is carried out using dual extruder rapid prototyping (RP) machine. The RP machine used has an enclosed chamber that helps in limiting the influence of environmental conditions like moisture, dust etc. The machine has a positional accuracy of 2.8 microns. The benchmark part was not finished manually but using acetone finishing to improve the part quality and get it close to its CAD model. For contactless scanning, a thin layer of white powder is sprayed on the benchmark part for effective optical scanning of the part. In past research, it was verified that such layer doesn't affect the results of non-contact measurements. Additionally, it helps in converting the reflective surface to suitable one for optical scanning.

\subsection{Common reference system definition (Contact and non-contact)}

For effective and accurate comparison, it is imperative to define the common reference system for part alignment in contact as well as non-contact systems with minimum error (Yau et al., 2000; Wolf et al., 2000). For contact-based measurement, a part reference system was used. However, in case of non-contact digitization, the 3D point cloud data acquired are related to the machine reference system. In literature, quite a few methods are available to perform the part alignment (Van Gustel et al., 2008; Martinez et al., 2008). This work considered one of the most common methods used in the literature by positioning three equal size spheres on the benchmark part (see Figure 3) and scanning them along with the surface of the part. Further, the sphere surfaces were reconstructed and their centers and the distance between their centers are used to establish the common reference system. Since the accuracy of the reconstructed surface is greatly influenced by registration, so the error in the sphere measured data must be evaluated. The comparison of the spheres surface is performed using the INSPECT PLUS software. For characterization of contactless scanner, it is required to consider the CMM measurement as reference and the scanner measurement as test values. For effective alignment the centre of the sphere sampled using CMM is matched with centre of sphere captures using scanner as shown in Figure 4.

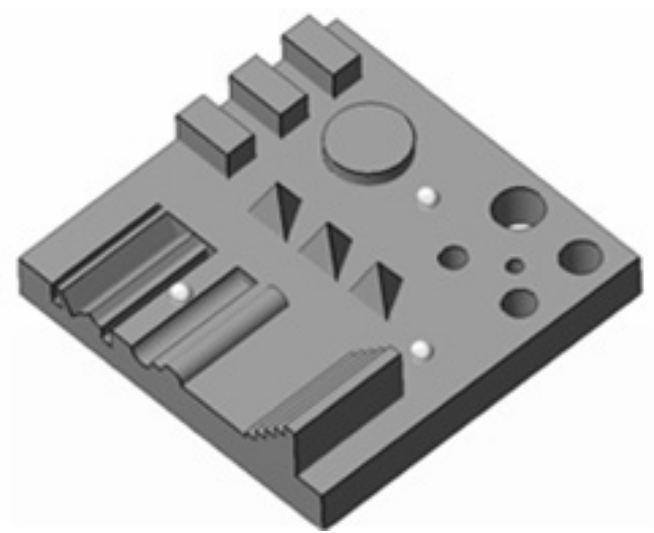

Figure 3. Benchmark part with three similar spheres for establishing common reference system

From Figure 4, it is observed that the coordinate value sampled from CMM are different from laser coordinate value especially along $\mathrm{z}$ axis. In addition, the radius of the three sphere seems to be different. For confirming, radius of the three spheres (16.5 diameter) placed over benchmark part is measured using touch probe CMM and laser scanner. For contact less scanning, different head orientation strategies adopted which results in 2, 4, 6 and 10 scans for each sphere. The results are reported in Figure 5. It was found that the radius of the spheres is changing irrespective of whether only two or more scans are performed. However, one important observation was decrease in the radius of the all the sphere as the number of scans are increasing. The difference in the radius of sphere when using 2 scans and 10 scans is in the range of $15-20 \mu \mathrm{m}$. This difference is quite insignificant, and it is closer to the reference values of the contact based CMM system.

\subsection{Non-Contact digitization strategy}

The first and foremost step of the non-contact scanning process is to define optimum scanning parameters. The scanning parameters can significantly influence the final results of the scanned model. The optimum parameter values will help in acquiring maximum point cloud data with minimum dispersion. The scanning distance and scanning incidence angle are fixed at $60 \mathrm{~mm}$ and $40-45^{\circ}$ respectively for improved scanner output. The COMET PLUS software was used for matching of scans, scanning paths and building up of the surface model. 


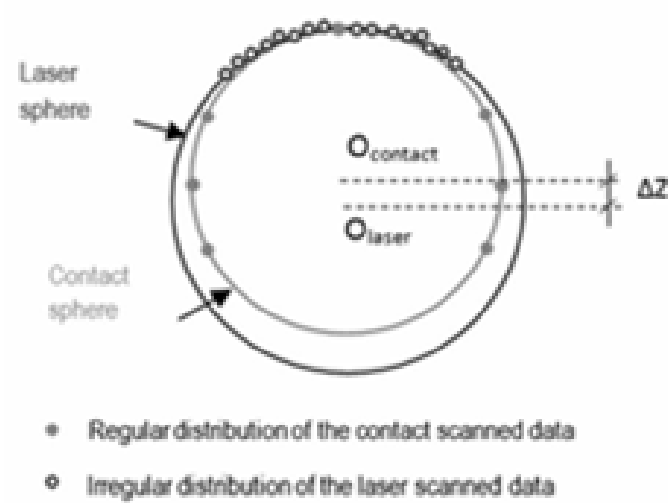

Figure 4. Sphere matching after part alignment

Further, two different head orientation techniques for part scanning was used. First strategy deals with fixing the head of the scanner at one place using minimum rotation and rotating the table by $5^{\circ}$ and capturing the part. The second strategy deals with moving the scanner head orientation and scanning individual components of the part, thus removing the occlusion. The next important step is the processing of unorganized raw point clouds. The redundant points were removed manually using the cutting tools provided in the COMET PLUS interface. Finally, the point cloud data are exported in STL format for surface reconstruction in the next stage.

Figure 5 shows sphere radius variation for part alignment. The first and foremost step of the noncontact scanning process is to define optimum scanning parameters. The scanning parameters can significantly influence the final results of the scanned model. The optimum parameter values will help in acquiring maximum point cloud data with minimum dispersion. The scanning distance and scanning incidence angle are fixed at $60 \mathrm{~mm}$ and $40-45^{\circ}$ respectively for improved scanner output. The COMET PLUS software was used for matching of scans, scanning paths and building up of the surface model.

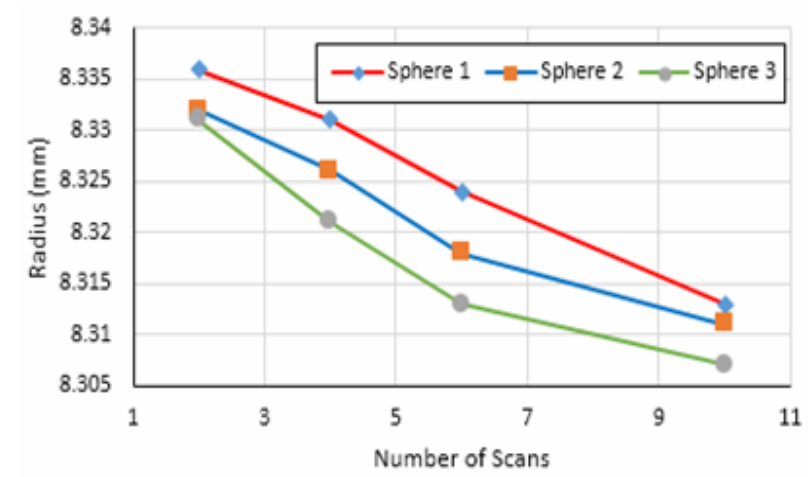

Figure 5. Sphere radius variation for part alignment

Further, two different head orientation techniques for part scanning was used. First strategy deals with fixing the head of the scanner at one place using minimum rotation and rotating the table by $5^{\circ}$ and capturing the part. The second strategy deals with moving the scanner head orientation and scanning individual components of the part, thus removing the occlusion. The next important step is the processing of unor- ganized raw point clouds. The redundant points were removed manually using the cutting tools provided in the COMET PLUS interface. Finally, the point cloud data are exported in STL format for surface reconstruction in the next stage.

\subsection{Surface reconstruction using different software}

Three different software interfaces are used for accurate surface reconstruction from unorganized raw point cloud data.

\section{-COMET PLUS}

-CATIA v5 (Digitized shape editor, quick surface reconstruction module)

-Solidworks (Scan-To-3D)

Initially, the benchmark part surface was reconstructed using touch probe CMM point data and considered as reference model for further comparison. Once all the point clouds are imported in the CAD interface, these are grouped according to the different features they belong to (cylinders, pyramids, blocks etc.). The process of surface reconstruction is simpler and faster for point clouds acquired using contact method. The possible reason being the uniform dispersion of point data at each surface. On the contrary, in contactless scanning the major concern is in determining the edges and boundary of the part surface and the dispersion of point data across the surface boundary. In addition, the points along the half cylinders and rectangular notches are difficult to determine and discriminate. Each of the region is fitted based on the adjacent region point data using the suitable algorithm in each CAD software.

It is seen that the best surface model was obtained for the former settings in Solidworks. The optimized path based on above analysis is considered for surface reconstruction process using CATIA v5 and Solidworks Scan-To-3D in adopted methodology (see Figure 6). The process of surface development in COMET plus is performed using its default settings. The path below can be directly used for surface reconstruction in digitized shape editor module (CATIA v5) and Scan-To-3D (Solidworks) is shown in Figure 6. The path for CATIA and Solidworks are found out using the above discussed methodologies, user working on this software can directly use the below mentioned parameters and get the improved final 3D model as shown in Figure 7.

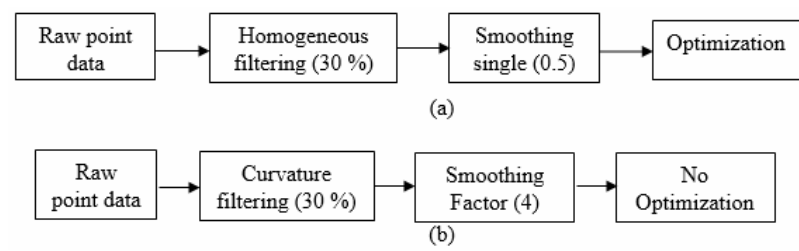

Figure 6. Optimal path for surface reconstruction (a) CATIA v5 (b) Solidworks

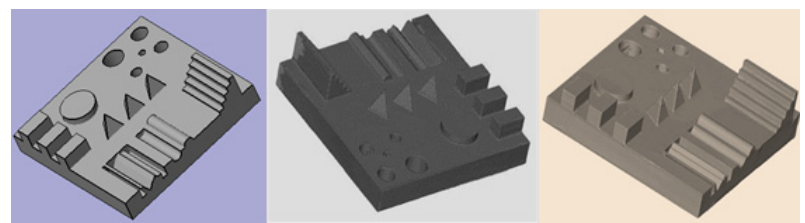

Figure 7. Surface model (a) CATIA v5 (b) COMET PLUS (c) Solidworks 


\section{COMPARISON OF SURFACE MODELS}

The INSPECT PLUS software application by Steinbichler is used for inspection of the surface reconstructed in the previous section. The surface as well as GD\&T deviations are compared, and results are presented. The surface and average deviations are displayed by the software in the form of coloured maps. The average deviations are simply the distance between a set of corresponding point data acquired in a given area of the part. Beginning with the importing of the CAD and scanned data in software, the next step is proper alignment. For comparison, 3-2-1 method was realized to perform suitable part alignment. The importance of 32-1 technique is that it restricts six degrees of freedom available for the models in space that helps in effective alignment. The main purpose of alignment is to bring the scanned data reference frame ( $\mathrm{X}, \mathrm{Y}$ and $\mathrm{Z})$ to the $\mathrm{CAD}$ data reference frame and origin.

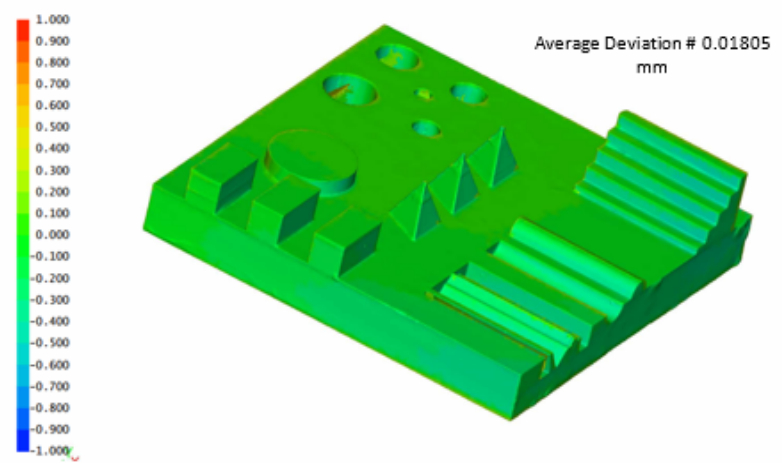

Figure 8. Average deviation comparison using contact and non-contact (CATIA v5) scanning

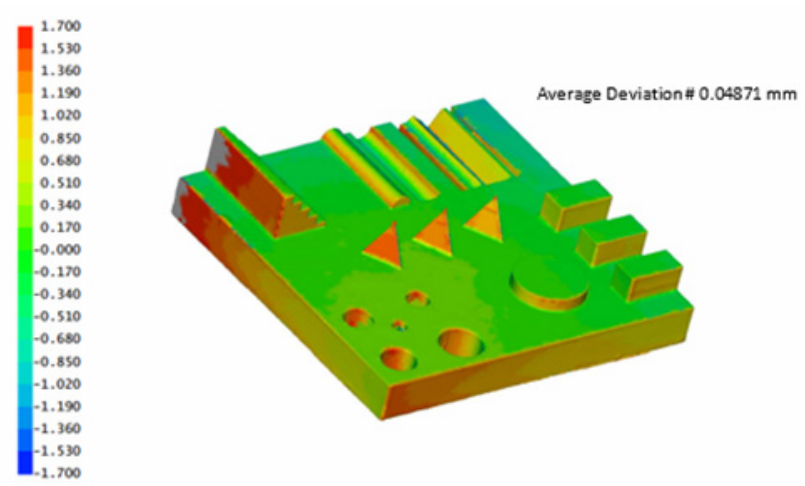

Figure 9. Average deviation comparison using contact and non-contact (COMET PLUS) scanning

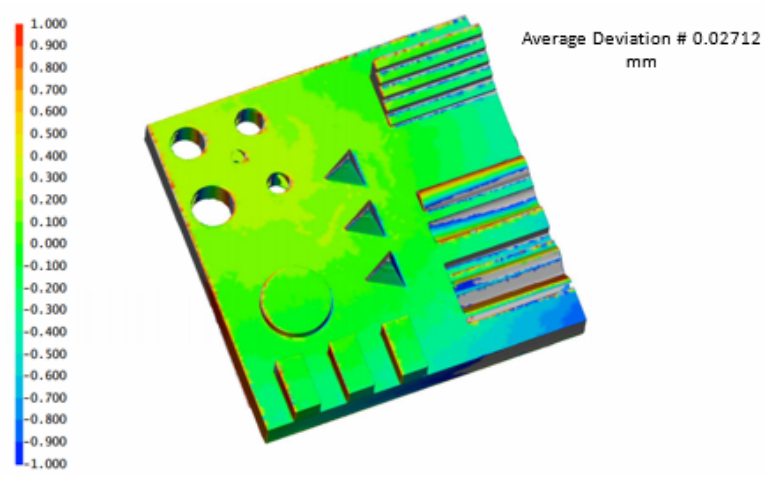

Figure 10. Average deviation comparison using contact and non-contact (Solidworks) scanning
Figures 8, 9 and 10 shows the average deviation between the surface reconstructed using contact point data (reference) and contactless point data using three chosen software applications. From figure 8 , it was found that the surface reconstruction is performed most accurately by CATIA v5 and the average deviation did not exceed $18 \mu \mathrm{m}$. All the individual features are reconstructed with absolute precision and improved accuracy. On the contrary, the COMET PLUS results are opposite to the CATIA as clearly seen from Figure 9.

The average deviation is around 2.5 times as compared to the CATIA v5 results. The holes, rectangular notches and the half cylinders edges are not reconstructed appropriately by the default COMET PLUS software application. The main reason being the scarcity of point data in these regions. In Solidworks Scan-To-3D module, the average deviation value is in between the CATIA and COMET PLUS which is approximately $27 \mu \mathrm{m}$. After the above comparison in contact point data and contactless acquired point data, point data dispersion (variation) is more in contactless scanning. Moreover, irrespective of the higher amount of data acquired, point data dispersion causes decrement in accuracy of the developed surface model. In addition, different software applications are useful in minimizing the deviation of scan data from the actual CAD model by applying various algorithms inbuilt in them.

\section{GEOMETRICAL COMPARISON OF RECONSTRUCTED SURFACE MODELS}

In this section, GD\&T comparison (flatness, cylindricity, parallelism, perpendicularity, angularity) along with the distance comparison was performed using INSPECT PLUS software application. The results of the distance comparison including the horizontal and vertical plane are shown in Figure 11. The vertical plane distances are marked as $d_{1}, d_{2}$ and $d_{3}$ respectively, while the horizontal plane distances are marked as $d_{4}, d_{5}$ and $d_{6}$. From Figure 11 (b), it was observed that CATIA and Solidworks results for vertical planes are having very minimum deviation from CMM data. The exact value of deviation is approximately $6 \mu \mathrm{m}$, which is negligible as compared to the test data of CMM. However, the results of default COMET data is worst, similar to the earlier results of $3 \mathrm{D}$ deviations. The variation in the maximum and minimum deviation for COMET PLUS software is around $40 \mu \mathrm{m}$.

Furthermore, the comparison results for horizontal planes are reported in Figure 11 (c). The results displayed shows that the deviation increases nearly two times to $11 \mu \mathrm{m}$ for chosen horizontal planes. Moreover, the distance and shows significant variation for CATIA, Solidworks and COMET reconstructed surface.

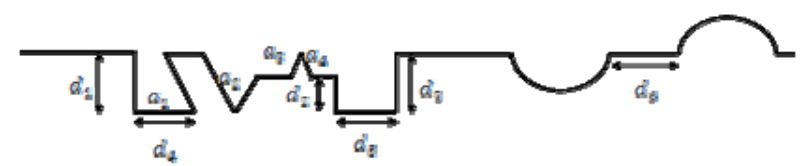

(a) 


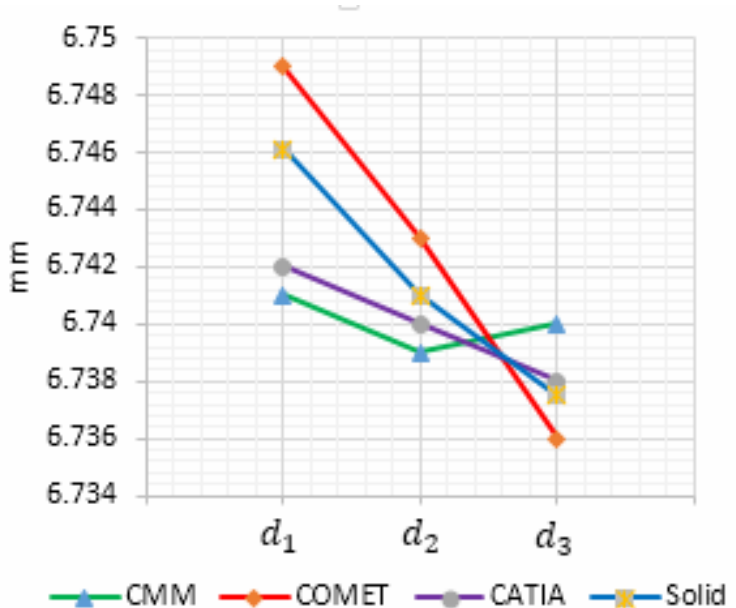

(b)

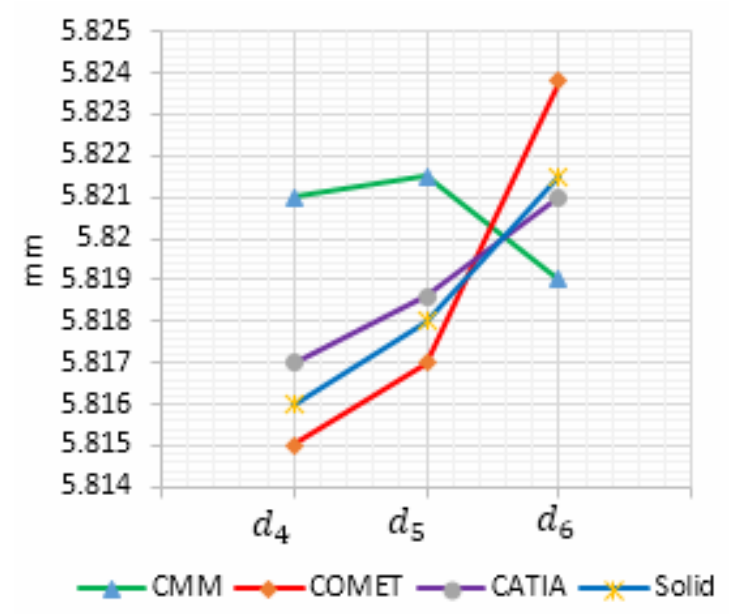

(c)

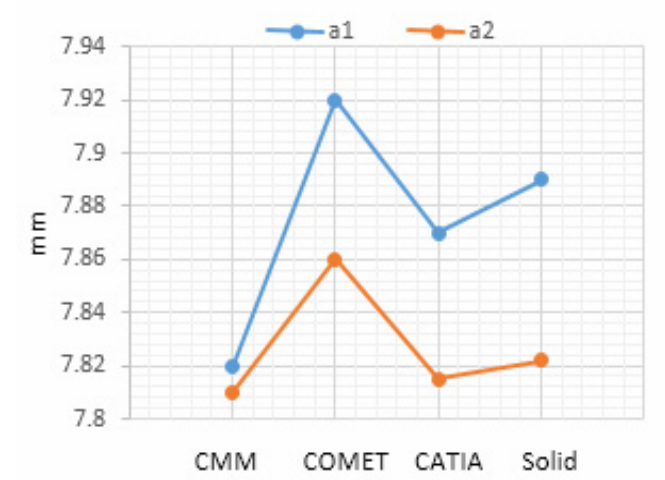

(d)

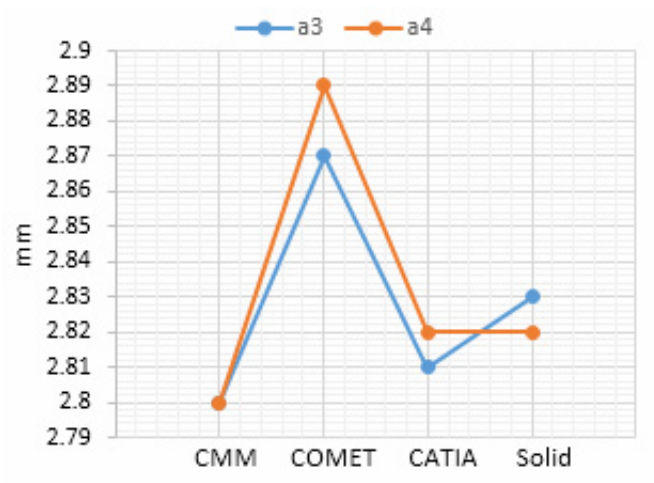

(e)

Figure 11. Distance comparison of benchmark part for (b) vertical (c) horizontal planes (d) angular planes
The possible reason being the scarcity and incomplete point data captured during the scanning of these inner notches. The positive deviation of distance is because of the good quality of points acquired during scanning of flat surface. Like the previous results, the COMET surface deviation is worst among the three application software results. Further, the angular dimensions are marked as $a_{1}, a_{2}, a_{3}$ and $a_{4}$. Figure 11 (d) shows the result of angular dimension measurement and comparison of different application with contact based CMM measurement. The angular distance $a_{1}$ comparison with CMM test data shows significant difference in the contactless data captured. The CATIA result itself shows difference of nearly $35 \mu \mathrm{m}$ and Solidworks result shows deviation of approximately $55 \mu \mathrm{m}$. The primary reason being the non-availability of adequate number of point clouds due to occlusion phenomena. In contrast, the deviation for angular distance $a_{2}$ has reduced inversely reporting only $10 \mu \mathrm{m}$ difference. The COMET results are also having improved accuracy with deviation of $30 \mu \mathrm{m}$. There are no significant differences for angular distances $a_{3}$ and $a_{4}$ as the upper surface points are of good quality and large in number.

Seeing the above results, the CATIA application software is providing the best output. So, for GD\&T comparison study, the default software of Steinbichler i.e. COMET PLUS results are compared with CATIA v5 results. Moreover, GD\&T comparison of COMET PLUS and CATIA v5 reconstructed surface for the complete benchmark part is presented in Figure 12 and 13. Figure 13 illustrates the angularity and parallelism comparison at the angular pyramids and outer cylinder respectively. The angularity1 angularity2 is measured for angular pyramid AP1 and AP3 with reference to datum plane A. The parallelism1 is measured for outer cylinder OC with reference to datum A. The Figure 12 (a) depicts the CATIA results having the parallelism1, angularity 1 and angularity 2 values are $0.085,0.016$ and $0.040 \mathrm{~mm}$ respectively. The default parameters COMET results are illustrated in Figure 12 (b). It is observed that parallelism1, angularity1 and angularity2 values are $0.115,0.152$ and $0.092 \mathrm{~mm}$ respectively. It is clearly found that these GD\&T errors have significantly reduced using CATIA v5 application. Overall, the percentage improvement is around $12.3 \%, 66.38 \%$ and $89.47 \%$ for adopted CATIA methodology.

Similarly, Figure 13 (a-b) shows the GD\&T error results for flatness, parallelism and perpendicularity. Flatness 1 and flatness 2 are measured for blocks of flat surfaces FS2 and FS3. The parallelism2 error is measured for FS2 block with reference to datum A. At last the perpendicularity error is also measured for FS2 block with reference to datum A. It is observed that Flatness1, flatness2 and parallelism2 values are 0.043, 0.096 and $0.01 \mathrm{~mm}$ respectively. Similar to the previous results, it is clearly found that these GD\&T errors have significantly reduced using CATIA v5 application. Overall, the percentage improvement is around 20\%, $38 \%$ and $77 \%$ respectively for adopted CATIA methodology.

Finally, circularity measurement was performed for five inner cylinders IC1, IC2 IC3, IC4 and IC5. The $\mathrm{CMM}$ point data is easily acquired and cylinders are 
reconstructed easily. However, the laser point cloud data are not acquired adequately, especially in the vertical direction of the cylinder.

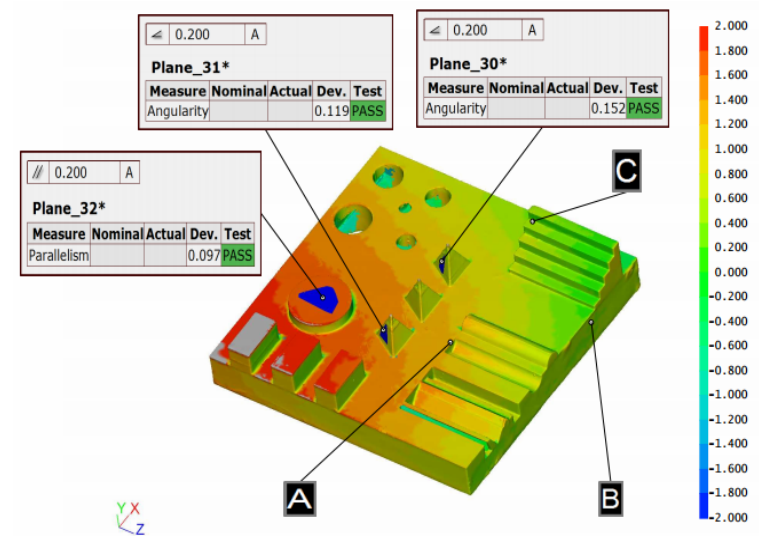

(a)

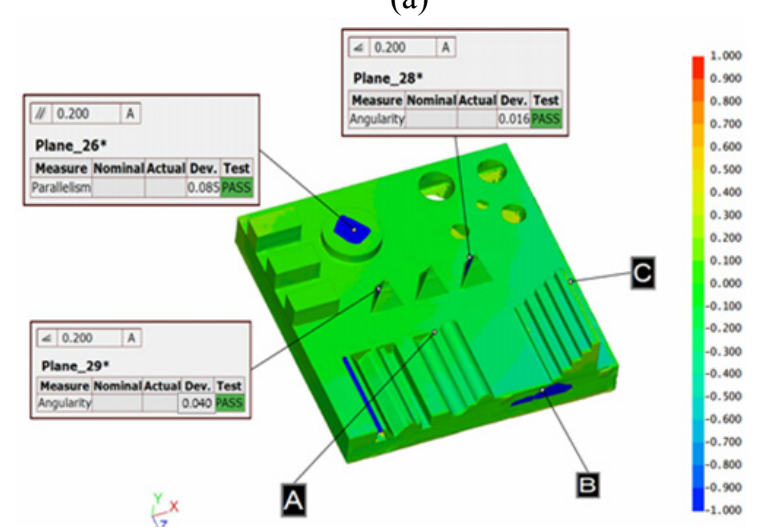

(b)

Figure 12. GD\&T results for (a) CATIA and (b) COMET PLUS developed surface

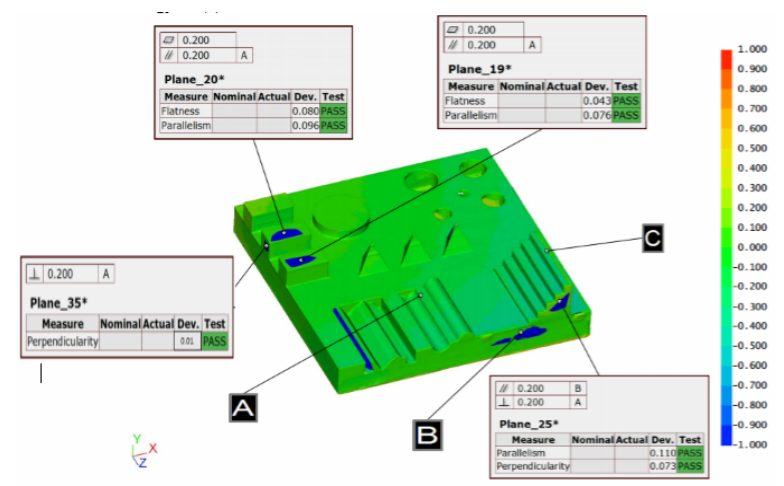

(a)

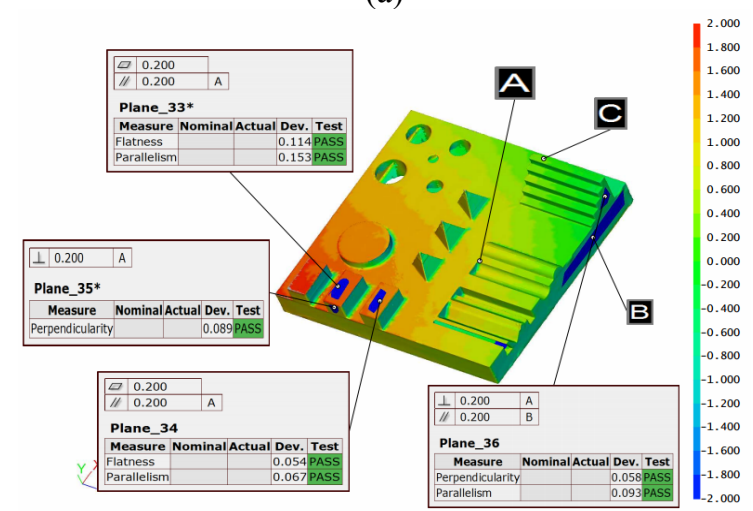

(b)

Figure 13. GD\&T results2 for (a) CATIA and (b) COMET PLUS developed surface

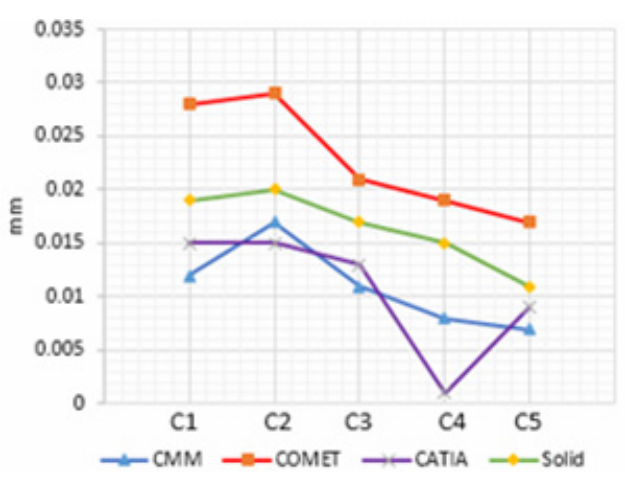

Figure 14. Circularity comparison of the reconstructed surface

So, the surface reconstruction was become possible when a multi-oriented strategy was considered, acquiring the vertical point data. The results of CATIA v5 and Solidworks comparison with CMM data are illustrated in Figure 14. It was found that the circularity is decreasing as the size of hole is decreasing. The possible reason being less number of points are required for reconstructing small holes. Finally, all GD\&T results are reported in Figure 15, with the percentage improvement by considering adopted methodology. It is evident from the results that maximum improvement in results is obtained for angularity and perpendicularity features in the benchmark part.

\section{CONCLUSIONS}

This paper presents an iterative framework that would be a handy tool to quality inspectors as it provides the systematic guideline to be followed in an automated GD\&T inspection system using contactless scanning systems. For validating the proposed framework, a novel benchmark part consisting of canonical features for the GD\&T verification of contactless laser scanning. Since, very few methodologies and standard parts are available for metrological verification and testing of non-contact sensor system, particularly for GD\&T features. The effect of different CAD systems utilized for surface reconstruction and GD\&T was also considered. For accurate comparison and measuring deviations of contactless scanners acquired data, contact based touch probe CMM sampling data is taken as reference. However, the contactless scanning system surface reconstruction was not easy as several features are difficult to capture, especially the holes with larger depth. The cylindrical parts are captured with more ease and reconstructed with minimum errors.

It is worth mentioning that the number of points captured by laser system is far higher than contact based system. Consequently, the accuracy will be more as number of points is higher, however, it can also affect the accuracy. For effective laser scanning, the surface reconstruction became possible when a multi-oriented strategy was considered, acquiring the vertical point data more easily. From CAD point of view, CATIA v5 application software (digitized shape editor module) has best results compared to Solidworks (scan-to-3D) and default software of scanner COMET PLUS. The proposed inspection framework and benchmark part was designed keeping in mind the common features used in industries and it will prove to be an effective reference tool which has almost all available GD\&T features. 


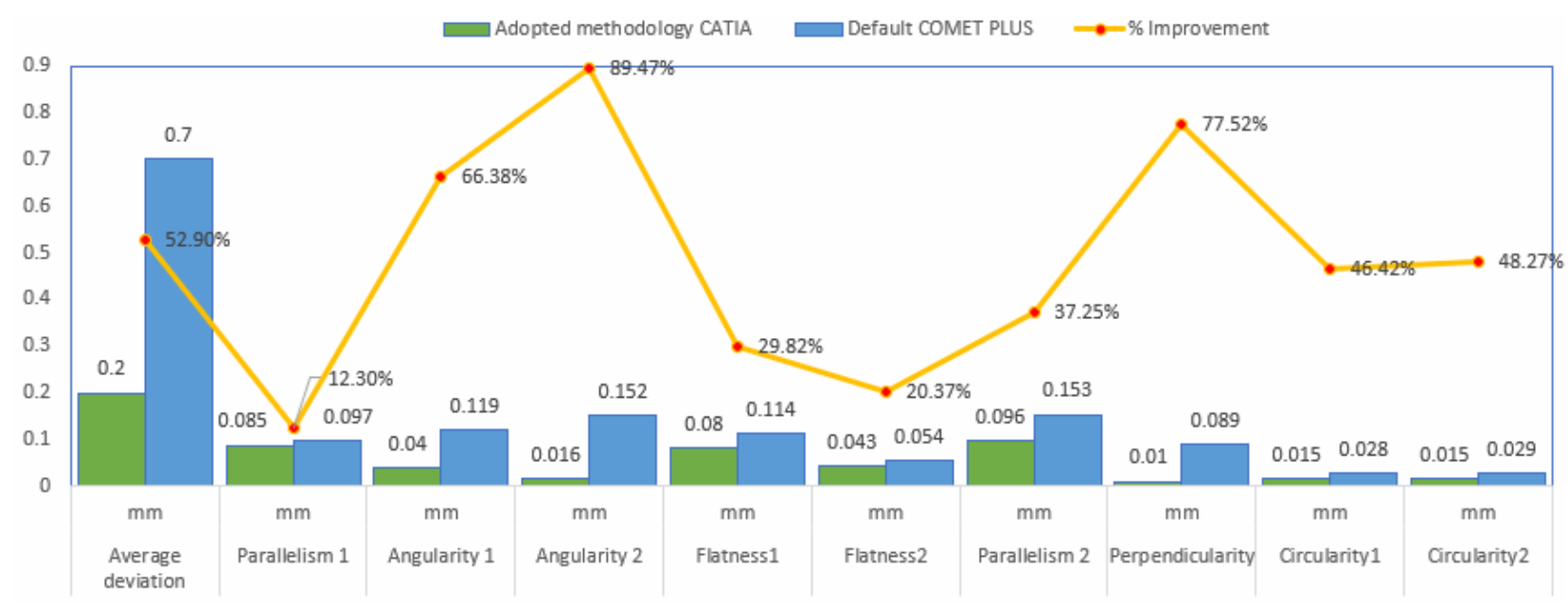

Figure 15. Results comparison for adopted methodology (CATIA) and default COMET PLUS

\section{CONFLICT OF INTEREST}

The authors declare that they have no conflict of interest.

\section{REFERENCES}

[1] Liu, R., Wang, Z., Sparks, T., Liou, F. Newkirk, J.: Aerospace applications of laser additive manufacturing. In Laser Additive Manufacturing 2017: 351-371.

[2] Pathak, V.K., Nayak, C., Singh, A.K., Chaudhary, H.: A virtual reverse engineering methodology for accuracy control of transtibial prosthetic socket. Biomedical Engineering: Applications, Basis and Communications, Vol. 28, No. 5, pp. 1650037, 2016.

[3] Hackney, P.M., Wooldridge, R.: 3D sand printing for automotive mass production applications. International Journal of Rapid Manufacturing, Vol. 6, No. 2-3, pp. 134-154, 2017.

[4] Gaub, H.: Customization of mass-produced parts by combining injection molding and additive manufacturing with Industry 4.0 technologies. Reinforced Plastics, Vol. 60, No. 6, pp. 401-404, 2016.

[5] Lee, K.H., Park, H.P.: Automated inspection planning of free-form shape parts by laser scanning. Robotics and Computer-Integrated Manufacturing, Vol. 16, No. 4, pp. 201-210, 2000.

[6] Son, S., Park, H., Lee, K.H: Automated laser scanning system for reverse engineering and inspection. International Journal of Machine Tools and Manufacture, Vol 42, No. 8, pp. 889-897, 2000.

[7] Feng, H.Y., Liu, Y., Xi, F.: Analysis of digitizing errors of a laser scanning system. Precision Engineering, Vol. 25, No. 3, pp. 185-191, 2001.

[8] Yadong, L., Peihua, G.: Free-form surface inspection techniques state of the art review, ComputerAided Design, Vol. 36, pp. 1395-1417, 2004.

[9] Elkott, D.F. et al.: Automatic sampling for CMM inspection planning of free-form surfaces. International Journal of Production Research, Vol. 40, No. 11, pp. 2653-2676, 2002.

[10] Bagci, E.: Reverse engineering applications for recovery of broken or worn parts and re-manufacturing: Three case studies. Advances in Engineering Software, Vol. 40, No. 6, pp. 407-418, 2002.
[11] Geng, Z., Bidanda, B.: Review of reverse engineering systems-current state of the art. Virtual and Physical Prototyping, Vol. 12, No. 2, pp. 161-172, 2017.

[12] Carbone, V., Carocci, M., Savio, E., Sansoni, G., De Chiffre, L.: Combination of a vision system and a coordinate measuring machine for the reverse engineering of freeform surfaces. The International Journal of Advanced Manufacturing Technology, Vol. 17, No. 4, pp. 263-271, 2001.

[13] Pathak, V.K., Singh, A.K.: Optimization of morphological process parameters in contactless laser scanning system using modified particle swarm algorithm. Measurement, Vol. 109, pp. 27-35, 2017.

[14] Kunzmann, H., Trapet, E., Wäldele, F.: A uniform concept for calibration, acceptance test, and periodic inspection of coordinate measuring machines using reference objects. CIRP Annals-Manufacturing Technology, Vol. 39, No. 1, pp. 561-564, 1990.

[15]Hansen, H.N. and De Chiffre, L.: A combined optical and mechanical reference artefact for coordinate measuring machines. CIRP Annals, Vol. 46, No. 1, pp. 467-470, 1997.

[16] Trapet, E., Savio, E. and De Chiffre, L.: New advances in traceability of CMMs for almost the entire range of industrial dimensional metrology needs. CIRP Annals-Manufacturing Technology, Vol. 53, No. 1, pp. 433-438, 2004.

[17] Pathak, V.K., Singh, A.K., Sivadasan, M., Singh, N.K.: Framework for automated GD\&T inspection using 3D scanner. Journal of The Institution of Engineers (India): Series C, pp 1-9, 2016.

\section{МЕТОДОЛОГИЈА ЗА ВЕРИФИКАЦИЈУ ГЕОМЕТРИЈСКЕ И ДИМЕНЗИЈСКЕ ТОЛЕРАНЦИЈЕ ИНОВАТИВНОГ РЕФЕРЕН- ТНОГ ДЕЛА КОД БЕЗКОНТАКТНИХ СИСТЕМА ЗА СКЕНИРАЫЕ}

\section{В. Патак, А.К. Шривастава, С. Гупта}

Рад приказује иновативни метод истраживања прецизности и могућности система за безконтактно 
ласерско скенирање са аспекта контроле геометријске и димензијске толеранције. Предлаже се коришћење стандардног референтног дела са типичним карактеристикама које одговарају фамилији димензионисања и толеранције. Израђени референтни део има различите карактеристике прописане у техници и индустрији. Усвојени приступ обухвата методологију за упоређивање геометрије применом методе подешавања код безконтактних система за скенирање и СММ машина. Такође су примењене различите методе оријентационог скенирања. Инжењерски софтвер је коришћен за површинску рекон- струкцију референтног модела и резултати су анализирани да би се утврдила корелација између различитих геометрија контактног и безконтактног система за скенирање. Коришћењем мерења базираног на контакту, као референтног, различити развијени модели су анализирани и упоређивани према геометријској и димензијској толеранцији. Предложени стандардни референтни део и методологија верификације геометријске и димензијске толеранције омогућава једноставан и ефикасан начин евалуације различитих безконтактних ласерских скенирајућих система са аспекта одступања. 